\section{Soviets soften on psychiatry?}

REPORTS from Moscow suggest that, for the first time, the Soviet psychiatric establishment is willing to engage in cautious dialogue with dissidents over alleged cases of political abuse of psychiatry. the unofficial Moscow "Working commission for investigating the use of psychiatry for political purposes" (an adjunct of the Helsinki monitoring group) has been publishing regular reports of such cases. In Bulletin 13 (November, 1978), it reported the case of Yurii Zakharovich Valov, hospitalised apparently for having made repeated protests to the media against what he saw as unfair dismissal from his job in an engineering works. The diagnosis was not revealed; however, it was known that Valov had been pre-

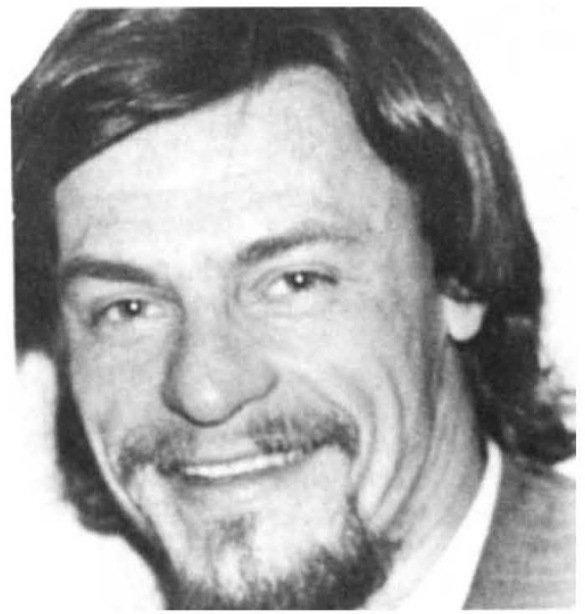

Dr Aleksandr Voloshanovich: asked to advise insulin and chlorpromazine. since last April. been mentioned. indicated.
Since its foundation in January 1977 ,

scribed heavy medication-including

The latest bulletin, number 14 (January 1979), takes up the case again. According to Soviet practice, Valov's case was to be reviewed by a medical commission on 7 December. As well as the regular establishment doctors, a representative of the working commission was invited to be present-Dr Aleksandr Voloshanovich, a psychiatrist, who has been acting as a consultant for the working commission

The official report on the Valov case stated that Valov was in need of "biological treatment, psychotherapy, and subsequent socio-psychiatric measures". The exact grounds for this recommendation are not entirely clear though "personality disorders" have

Dr Voloshanovich agreed with the need for psychotherapy and "sociopsychiatric measures" (whatever they may be), but he denied that hospitalisation and the use of neuroleptics were

This is by no means the first case where extreme psychiatric measures were employed, on political grounds, against a person suffering from a mild psychological disorder. The invitation to Dr Voloshanovich to sit in on the case may well reflect a double approach to the working commission-a desire for cautious dialogue combined with a wish to obtain at least a partial confirmation of the official verdict.

Vera Rich

\section{Shortage of technologists in USSR}

INTEGRATION of research and industry is a fundamental tenet of Soviet science policy. It is the rationale behind the establishment of a network of 'science centres' throughout the country, and the occasional Party censure of individual research bodies which neglect the industrial problems of their local area.

In recent months, however, official emphasis has been turning away from the role of the scientists in the 'scientific-technological revolution' to that of the technologists. Last July, Mr Brezhnev told the Plenum of the Central Committee that the shortage of middle-level managers and department heads in factories was disquieting, while in agriculture only $40 \%$ of such posts are filled.

Last week, Pravda took up the case of other organisations including scientific research institutes, where there is also a serious lack of middle-level staff. The problem seems to be a dual one: the actual training of the required personnel and their deployment once they have qualified.

Technical college admissions, says Pravda, are constantly increasing (almost 1.5 million new enrolments last autumn). Nevertheless, it comments, "training has to be formulated taking into account long-range forecasts of the development of science and industry", which suggests that certain courses need re-designing and/or upgrading.

At the same time, the deployment of the present work-force of middle-level technologists-the "sergeants of industry" - is far from at its best.

The Pravda editorial (a traditional way of launching a new efficiency drive), calls for the relevant Party and Trade Union Committees, and the AllUnion and Republic Ministries of Higher Education, to "analyse and eliminate" these defects.

\section{British scientists help Chinese set up new university}

THE UK is to help China set up and run an English-speaking technical university. The idea for such a collaboration was first raised last November when a high-level delegation from the Chinese Academy of Sciences visited the UK. British officials showing the delegation around scientific establishments were taken by surprise by the proposal, which was announced towards the end of the visit. It was not clear, according to John Deverill of the Royal Society, whether the Chinese decided to propose the cooperation on the spur of the moment or whether they had planned it before their visit.

The university is to be established at Chengtu, the capital city of Szechuan, a province of central China covering $6 \%$ of the country's land area and containing $10 \%$ of its population. Chengtu Technical College, which has 2,800 students, 1,190 academic staff, and five departments is to be expanded to include 5,000-6,000 undergraduates, 1,500 postgraduates and 13 departments and given university status. The vice-chancellor will probably be $\mathrm{Mr}$ Ma Shih-tu, vice-president of the Chengtu branch of the Chinese Academy of Sciences.

The key UK bodies involved in the operation will be the Royal Society and the British Council, though no one is yet sure what it all entails. "The Royal Society is not set up to start universities in other people's countries", $\mathrm{Mr}$ Deverill says, but he thinks it could be arranged for academics to spend some time-from one to three years-at Chengtu helping to set up new departments and start new courses. The British Council will probably help establish English courses and arrange for English teachers to spend time there. The administration and funding of the university, however, are likely to be left to the Chinese. A delegation of British officials and academics now visiting China is assessing more precisely how the UK can help at Chengtu.

Chengtu will be unique as the only exclusively English-speaking university in China. The Chinese Academy of Sciences runs two other partially English-speaking universities at Hangchou and Hofei, and one partially Japanese-speaking university at Harbin. The Chinese Ministry of Education used to run French and Germanspeaking universities in Shanghai. There is a possibility that both these could be restarted with French and German help.

Judy Redfearn 